\title{
Management of chemotherapy-related symptoms in children and adolescents: family caregivers' perspectives
}

\author{
Gerenciamento dos sintomas relacionados à quimioterapia em crianças \\ e adolescentes: perspectivas de cuidadores familiares \\ Gestión de los síntomas relacionados con la quimioterapia em niños \\ y adolescentes: perspectivas de cuidadores familiares
}

How to cite this article:

Silva-Rodrigues FM, Lucca M, Leite ACAB, Alvarenga WA, Nunes MDR, Nascimento LC. Management of chemotherapy-related symptoms in children and adolescents: family caregivers' perspectives. Rev Esc Enferm USP. 2021;55;e20200484. doi: https://doi.org/10.1590/1980-220X-REEUSP-2020-0484.

Fernanda Machado Silva-Rodrigues ${ }^{1}$

Milena de Lucca²

Ana Carolina Andrade Biaggi Leite ${ }^{2}$

Willyane de Andrade Alvarenga ${ }^{3}$

Michele Darezzo Rodrigues Nunes ${ }^{4}$

Lucila Castanheira Nascimento ${ }^{2}$

${ }^{1}$ Faculdade de Ciências Médicas da Santa Casa de São Paulo, São Paulo, SP, Brazil.

${ }^{2}$ Universidade de São Paulo, Escola

de Enfermagem de Ribeirão Preto,

Ribeirão Preto, SP, Brazil.

${ }^{3}$ Centro Universitário Santo

Agostinho, Teresina, PI, Brazil.

${ }^{4}$ Universidade do Estado do Rio de Janeiro, Faculdade de Enfermagem, Rio de Janeiro, RJ, Brazil.

\section{ABSTRACT}

Objective: To describe the chemotherapy-associated symptoms and the strategies used for their management from the perspective of pediatric cancer patients' family caregivers. Methods: This is a descriptive study with qualitative data analysis. Data collection took place in a pediatric hospital, from December 2017 to December 2018, with family caregivers of pediatric patients undergoing chemotherapy. Semi-structured interviews, subjected to inductive content analysis, were carried out. Concepts from the Symptom Management Theory were used to discuss the results. Results: Eighteen family caregivers participated. The participants mentioned: physical symptoms, especially weakness, alopecia, low immunity, pain, mucositis, constipation, nausea, and vomiting; emotional or psychosocial symptoms such as sadness and mood changes; and constitutional symptoms such as loss of appetite and fever. Pharmacological and non-pharmacological measures were mentioned in the management of symptoms and adverse effects. Conclusion: Participants demonstrated skills to identify and manage symptoms of chemotherapy. Knowing the experience of these families can help nurses in planning care and interventions to minimize these events.

\section{DESCRIPTORS}

Neoplasms; Drug Therapy; Drug-Related Side Effects and Adverse Reactions; Caregivers; Pediatric Nursing. 


\section{INTRODUCTION}

Childhood cancer corresponds to a group of diseases sharing the uncontrolled proliferation of abnormal cells. ${ }^{(1)}$ In the United States, its incidence increases slowly each year and, by 2020,11,050 new cases among individuals aged zero to 14 years are estimated. ${ }^{(2)}$ In Brazil, cancer represents the leading cause of death from disease among children and adolescents from 1 to 19 years, and for 2020, 8,460 new cases of the disease are estimated.(1) Childhood cancer predominates in men, and the most common types are leukemia, central nervous system tumors, and lymphomas. ${ }^{(1-2)}$

Chemotherapy is the main cancer treatment modality. ${ }^{(3)}$ The 5-year overall survival rate for all childhood cancers has improved markedly over the past 30 years, thanks to modern and selective chemotherapeutics. ${ }^{(4)}$ Despite their effectiveness, these drugs do not differentiate normal cells from cancerous ones and cause several adverse effects. ${ }^{(3)}$ Adverse effects are those harmful, undesirable and observable, which can occur during and/or after interventions and use of medication. Effects are considered adverse when it is possible to establish a causal relationship between the drug treatment and the observed effect. ${ }^{(5-6)}$ They are considered symptomatic when they alter the body's functioning and, in these cases, they are called symptoms. These are usually noticeable and can be reported by the patient or caregiver. ${ }^{(7)}$

The treatment of childhood cancer causes symptoms and adverse physical, emotional, and psychosocial effects, such as pain, nausea, vomiting, fatigue, alopecia, mucositis, immunosuppression, sleep disorders, and appetite and emotional changes. ${ }^{(4,8)}$ The identification and assessment of these events challenge clinical practice, as they require professionals to deal with a complex biopsychosocial process and to analyze factors through observation, the child's self-report, and the parents' report. ${ }^{(9)}$

Generally, the family is responsible for following the child/adolescent during treatment, and the mother is usually the primary caregiver. ${ }^{(10)}$ Caregivers, by spending more time with children/adolescents, become capable of identifying therapy-related changes and symptoms and are allies of health care professionals. ${ }^{(9-10)}$

The literature presents several methodologies and perspectives on the management of symptoms related to cancer treatment. ${ }^{(11-14)}$ However, no studies were identified that explored symptoms resulting from chemotherapy and their management, according to the experiences of family members of children/adolescents with cancer, and that discussed their data in the light of the Symptom Management Theory (SMT). ${ }^{(15)}$ This theory provides three essential concepts: experience with the symptom, strategies for its management, and results arising from the symptom. In studies in the pediatric area, it was used only in the context of asthma and HIV..$^{(16-17)}$

This study sought to answer the questions: "How are the chemotherapy-associated symptoms described by family caregivers of children and adolescents with cancer? What strategies do they use for their management?"
This study aimed to describe the chemotherapyassociated symptoms and the strategies used for their management from the perspective of pediatric cancer patients' family caregivers.

\section{METHOD}

\section{Study Type}

This is a descriptive study with qualitative data analysis, which used SMT concepts ${ }^{(12,15,18)}$ to better understand and discuss the experiences of caregivers of children/adolescents undergoing chemotherapy.

\section{LOCAL}

The study was carried out in a pediatric hospital in an inland city in the state of São Paulo, which serves twelve specialties and contains exclusive beds for chemotherapy. All pediatric unit wards have two beds, except for the respiratory isolation and contact wards, which are individual.

\section{Population}

Convenience sampling was used for selecting participants who met the inclusion criteria: family caregivers, older than 18 years, of children and adolescents who had undergone at least one complete cycle of chemotherapy. Family caregivers of children who were undergoing another treatment modality concomitantly with chemotherapy or who had no curative therapeutic possibilities were excluded. New participants recruitment was interrupted when the data set was sufficient to achieve the objective proposed in the research, with data quality for the understanding of the phenomenon under study and the scarcity of new elements for the planned analyses being observed, thus confirming the theoretical sufficiency of data. ${ }^{(19-20)}$

\section{Data Collection}

Data collection took place in the pediatric clinic of a public hospital in the state of São Paulo, from December 2017 to December 2018, through semi-structured interviews, with an average duration of 37 minutes and carried out in a single meeting with each participant. The location of the interview was selected by the participants themselves, with most of them $(n=15)$ preferring to remain next to the child or adolescent in the ward during the interview. Three of them decided that the interviews should be carried out outside the ward, in the cafeteria or playroom. Regardless of the location chosen, the researchers ensured the participants' privacy and comfort, providing a location with little noise and low flow of people.

Two researchers conducted the interviews: a nurse with experience in qualitative research, and a nursing student, trained and supervised by the research team. None of them was involved in the care of the children/adolescents nor had prior contact with the participants.

Before the interviews, the children's and adolescents' medical records were consulted to certify the diagnosis, stage of the disease, and treatment modality used. The first 
three interviews were carried out to verify the relevance of the script, previously elaborated by the authors and with questions that gradually introduced the interviewee to the investigated theme. Examples of these questions are: Tell me how you think chemotherapy works on your child's body (name of child/adolescent); What symptoms do you observe when your child (name of child/adolescent) receives chemotherapy?

\section{Data Analysis and Treatment}

The audio-recorded interviews were fully transcribed and analyzed concurrently with the collection, according to the steps of inductive content analysis: preparation, organization, and reporting of results. ${ }^{(21)}$ In the first, two researchers selected units of meaning, after successive readings of the statements. Data organization took place through coding, which allowed the selection of content to facilitate insights and abstractions by the researchers. Such content was synthesized and grouped by similarity into categories, validated by a researcher experienced in qualitative analysis. The results reporting phase is presented in categories, along with the frequency of symptoms and adverse effects reported, both validated by the authors. The guidelines of the Consolidated Criteria for Reporting Qualitative Research (COREQ) ${ }^{(22)}$ were followed to increase the rigor in reporting the research.

\section{ETHICAL AspeCts}

This study received ethical approval from the institutions involved, Opinion no. 2.561.591/18. Participants were informed about the research objectives and procedures for data obtainment and, with their consent, signed the Free Informed Consent Form. To preserve anonymity, the participants were identified with the letter $\mathrm{E}$, followed by the interview number (E1, E2 etc.).

\section{RESULTS}

Eighteen participants were interviewed, all women, namely: 15 mothers (83.5\%), one grandmother (5.5\%), one aunt (5.5\%), and one sister (5.5\%), aged between 20 and 60 years and a mean age of 33.6 years. The level of education ranged from complete or incomplete elementary education $(7 ; 38.9 \%)$, complete or incomplete high school grade $(8 ; 44.4 \%)$, to complete higher education $(3 ; 16.7 \%)$. The interviewees were from inland cities of the state of São Paulo $(16 ; 88.9 \%)$ and from other states $(2 ; 11.1 \%)$. The children and adolescents were between 1 and 15 years old (mean 8.4 years) and diagnosed with leukemia $(7 ; 39 \%)$, lymphoma ( $1 ; 5.5 \%)$, rhabdomyosarcoma $(3 ; 16.7 \%)$, osteosarcoma $(2 ; 11.1 \%)$, sarcomas $(1 ; 5.5 \%)$, and other solid tumors $(4 ; 22.2 \%)$.

The results were grouped into two themes: Symptoms and adverse effects of children and adolescents and Management of symptoms and adverse effects by family caregivers. The symptoms and adverse effects presented by children and adolescents and described by family caregivers, as well as the strategies used by them for their management, are represented in Chart 1.

\section{Symptoms and Adverse Effects in Childoren and AdolesCents}

Physical, emotional (or psychosocial) and general (or constitutional) symptoms were identified by the participants as related to chemotherapy. Among the main physical symptoms, gastrointestinal reactions (nausea and vomiting), during or after chemotherapy sessions, and constipation stood out.

He (child) gets a bit nauseous, makes bim want to vomit (E3). Bowel movements are completely off (E1).

Dysgeusia was also observed in children and adolescents, causing changes in dietary patterns. After chemotherapy,

Chart 1 - Symptoms and adverse effects in children and adolescents described by family caregivers and strategies used for their management - Ribeirão Preto, SP, Brazil, 2019.

\begin{tabular}{|c|c|}
\hline Symptoms and adverse effects in children and adolescents & Caregivers' strategies for managing symptoms and adverse effects \\
\hline Physical & \multirow{2}{*}{$\begin{array}{l}\text { Gastrointestinal changes, pain, and dermatological changes: } \\
\text { Offering of a diet rich in fruits and vegetables and increased water intake } \\
\text { Administration of prescribed medications } \\
\text { Encouragement of consumption of light and cold foods } \\
\text { Instruction on breathing techniques and the adoption of antalgic positions } \\
\text { Skin hydration }\end{array}$} \\
\hline \multirow{3}{*}{$\begin{array}{l}\text { Vomiting }(17 ; 94.4 \%) \text {, alopecia }(13 ; 72.2 \%) \text {, asthenia }(13 ; 72.2 \%) \text {, } \\
\text { pain }(11 ; 61.1 \%) \text {, nausea }(\mathrm{n}=11 ; 61.1 \%) \text {, decreased immunity } \\
(8 ; 44.4 \%) \text {, constipation }(6 ; 33.3 \%) \text {, dysgeusia }(5 ; 27.8 \%) \text {, } \\
\text { drowsiness }(5 ; 27.8 \%) \text {, and dermatological changes }(3 ; 16.7 \%) \text {. }\end{array}$} & \\
\hline & $\begin{array}{l}\text { Alopecia: } \\
\text { Encouragement of the use of adornments (caps and headbands) }\end{array}$ \\
\hline & $\begin{array}{l}\text { Immunity decline: } \\
\text { Suggestion on the use of colored or decorated surgical masks } \\
\text { Offering of natural juices, roots, ostrich oil, and medicinal herbal teas to enhance } \\
\text { the effects on immunity }\end{array}$ \\
\hline \multicolumn{2}{|l|}{ Emotional/psychosocial } \\
\hline $\begin{array}{l}\text { Sadness }(5 ; 27.8 \%) \text {, resentment }(5 ; 27.8 \%) \text {, crying spells }(5 ; \\
27.8 \%) \text {, and anger }(\mathrm{n}=4 ; 22.2 \%) \text {. }\end{array}$ & Relying on religious beliefs and hope for a cure \\
\hline General/constitutional & $\begin{array}{l}\text { Offering of attractive foods, well-tolerated dietary supplements and encouragement } \\
\text { for better food acceptance as a resource to improve general health }\end{array}$ \\
\hline
\end{tabular}


they stopped enjoying certain foods, and others began to accept only the food they preferred.

She (child) started having eating problems. After the chemotherapy started, she wanted to eat only French fries and pasta (E11).

Pain was the most mentioned physical symptom, mainly headache, low back pain, stomach pain, and arthralgia.

After he (adolescent) started chemotherapy, in addition to nausea, he has pain in his joints (E5).

Drowsiness and asthenia were also changes noted after chemotherapy was initiated.

If she (child) stands for a long time, she starts to want to lean on something, to squat, she can't stand it because she feels very weak (E7).

Regarding the observable physical adverse effects, almost all participants highlighted chemotherapy-induced alopecia.

She (child) always had a lot of hair on her legs, on her back. I see that little by little it is all falling (E17).

Other dermatological alterations were mentioned, mainly by family caregivers of dark-skinned children and adolescents, such as xeroderma and nails darkening and weakening.

The skin (became) very dry. You see it's a skin that has no life. You can moisturize it, but it's still pretty dry. (...) her nails (child) became weak and black (E13).

The participants mentioned mucositis as bothering adverse effects and immunity decline with apprehension due to the fearful infectious conditions that could affect children and adolescents during treatment.

The resistance of those undergoing chemotherapy is different. They are much more prone (to infections). In fact, she (child) has already got a fungal infection (E10).

She (child) had a wound in her mouth (E7).

Family caregivers also identified emotional and psychosocial changes resulting from the treatment, such as resentment and anger, especially in adolescents.

$\mathrm{He}$ (adolescent) is kind of 'down', kind of sad because he liked so much to ride a bike, stay in the street, fy a kite and now he can't. He gets sad (E9).

He (adolescent) was a little angry; he's been a little stressed. Sometimes he cries, he doesn't want to come (to the hospital), then he starts: 'I don't want to come anymore!' (E3).

One mother mentioned her teenage daughter's crying spell during a chemotherapy session, a reaction she considered frightening.

In chemotherapy, what scared me was her crying spell. She started chemotherapy and she just cried (E13).

Regarding the constitutional symptoms, common in other diseases, fever was mentioned briefly and was related to hospitalization as an oncological emergency.
Fever started and she was hospitalized (E14).

Loss of appetite was associated with physical symptoms, such as nausea, vomiting, and dysgeusia, and was considered a serious symptom, due to weight loss that worried caregivers.

I worry a lot about him not eating because he loses weight very fast; he has already lost 7kg (E6).

When asked about the course of treatment cycles and the manifestation of symptoms, five respondents stated that adverse reactions decreased over time:

In the beginning, the symptom was stronger because there was more chemotherapy. Then, as chemotherapy goes on, things get a little easier (E7).

Tiredness, he (adolescent) feels a lot. He felt a lot in the first phase. Now that he's going through the second, he's not. He's feeling better (E9).

Two mothers observed worsening as the treatment cycles passed.

In the beginning, he (child) did not have so many reports of symptoms and now he is having more (E4).

\section{Caregivers' Management of Symptoms and Adverse Effects}

Pharmacological and non-pharmacological measures were used by family caregivers to manage symptoms. The administration of prescribed medication, a diet rich in fruits and vegetables, and an increase in water intake were highlighted. To deal with loss of appetite, offering attractive foods, giving well-tolerated dietary supplements, and having stimuli such as "the better you eat, the faster you can be discharged" were strategies used by some caregivers.

After she (the child) started taking the medication, I started to improve the quality of her food, with fruits, vegetables and water as much as I could (E1).

Colored or decorated masks, to facilitate children's acceptance of their use in crowded places, were important resources to deal with the decline of immunity.

I even talked to the seamstress to make more masks, little models with pictures that she (child) wants (E17).

Complementary therapies based on natural juices, roots, ostrich oil, and medicinal herbal teas were mentioned to potentiate immunity.

I gave soursop pulp juice with yam. He drank it. It was good, it really even increased immunity (E12).

Pharmacological and non-pharmacological methods were used to relieve pain, nausea, and vomiting. One mother reported offering light, cold foods to relieve her son's stomach pain and mucositis. Increasing water intake and using breathing techniques were ways to relieve nausea. A mother also stated that her son adopted the antalgic position to relieve low back pain. 
We gave him plenty of liquid and medicines for nausea, but it didn't work much. When he started taking liquid, he started expelling the chemo... (E12).

And for vomiting, when she is like this, I say: 'Dear, breathe, breathe very hard, pull from the uterus' (E2).

For alopecia, the use of adornments, such as caps and headbands, alleviated the physical signs of chemotherapy.

He (adolescent) just got embarrassed because he wasn't used to being bald. Then my father bought him a cap (E9).

Strengthening religious beliefs and faith was important to promote well-being when facing emotional/psychosocial symptoms and hope for a cure.

We got closer to God, because in a situation like this we believe that God can heal (E9).

\section{DISCUSSION}

This study identified symptoms and adverse effects experienced by children and adolescents, as well as strategies used by family caregivers to minimize them. Although the symptom is a subjective experience, which reflects changes in the individual's biopsychosocial functioning, sensations, or cognition ${ }^{(18)}$, the participants were able to identify several chemotherapy-associated symptoms, as well as adverse effects.

The symptoms mentioned in the statements corroborate the literature, and the most cited were: pain, nausea and vomiting, loss of appetite, alopecia, constipation, weakness, sleep loss, and digestive disorders. ${ }^{(23-25)}$ Part of the symptoms mentioned were of a general or constitutional nature, that is, systemic symptoms, not specific and not restricted to cancer. ${ }^{(25)}$ In addition to the symptoms found in this study, the literature adds sweating, fatigue, and weight gain. ${ }^{(3,25)}$

Fatigue is a symptom widely mentioned as distressing and debilitating ${ }^{(8,26)}$, but it was not cited in the study. Its absence may be related to the lack of a well-established concept of fatigue in our culture, as well as to the low priority given to its recognition by healthcare professionals. ${ }^{(13)}$

The purpose of choosing symptom management strategies is to avoid or delay negative results. ${ }^{(22)}$ Among the strategies used by the participants, dietary changes to minimize epigastric pain and constipation and to increase immunity are highlighted. To minimize symptoms and adverse effects of chemotherapy, significant changes in the dietary pattern of families of children with cancer are generally reported. ${ }^{(27)}$

Among the strategies for coping with alopecia, family caregivers suggested the use of adornments. Changes in appearance probably affect the children's concept of selfperception and social acceptance and reflect parental concern with the psychosocial impact of the therapy's effects on their children, in addition to the physical impact itself. ${ }^{(3,28)}$ This concern is also observed with the use of colored masks, to facilitate their use. Studies identify the mask as an inconvenient for children and adolescents, as they cause shame and arouse unwanted looks ${ }^{(13)}$. Health education and emotional support are useful tools to minimize these feelings.
In this study, the concept of healing was associated with spirituality and hope. Spirituality was cited as a resource during treatment and as a complement to conventional therapy. ${ }^{(29-30)}$ These are important resources for coping with the adversities of the treatment, contributing to lower rates of anxiety and stress, ensuring satisfaction with therapy progress, preserving the belief in the possibility of the disease's transience and, mainly, enabling a glimpse of a cure. ${ }^{(29-31)}$ Based on SMT, the cultural environment, i.e., family beliefs, values, and practices affect both the selection of strategies for managing a symptom and its outcomes. It is important for nurses to identify and value family beliefs to strengthen their symptom management strategies.

Some participants reported improvement in symptoms over time, while others did not. SMT highlights that, like symptom manifestation, symptom management is a dynamic process, modified by individual assessments and influenced by factors such as how the individual conceives and responds to the experience of a particular symptom, the context in which the symptom emerges, and the present state of health-disease of the child/adolescent. ${ }^{(18)}$

Management strategies were not cited for several identified symptoms. Despite mentioning complementary resources for the relief of the treatment symptoms and adverse events, their still limited use may be due to the lack of knowledge about the use of these measures, as well as the limited preparation of these family caregivers to control the events, especially at home. ${ }^{(28)}$ According to SMT, all bothersome symptoms need to be managed. Therefore, the importance of the role of nursing in instructing families is highlighted, so that they feel capable of identifying and acting when facing symptoms. ${ }^{(22)}$

Possible limitations of the study are due to the unique research scenario and the different moments of treatment in which the children and adolescents were, considering the variability in the occurrence of symptoms during the antineoplastic therapy. Moreover, although this study included family caregivers, who were the key informants for understanding the phenomenon studied, the non-inclusion of male participants is considered a limitation, as it would make it possible to know the phenomenon investigated from the perspective of other family caregivers, such as fathers and grandfathers, for example.

\section{CONCLUSION}

Family caregivers identified symptoms and adverse effects of chemotherapy, and searched for strategies for its management, using pharmacological and non-pharmacological methods.

The strengths of this study are centered on the informants, who shared a wealth of essential data for studies of this nature, and on the diversity of oncological diagnoses and age range. This ensured a better understanding of the perspective of family caregivers regarding the investigated phenomenon. Armed with this knowledge, health care professionals, including nurses, can enable these families to identify the most prevalent symptoms and adverse effects that most afflict them, in addition to enabling them to control these events in the contexts in which treatment occurs, including home. 


\section{RESUMO}

Objetivo: Descrever os sintomas associados ao tratamento quimioterápico e as estratégias utilizadas para seu gerenciamento na perspectiva de cuidadores familiares de pacientes oncológicos pediátricos. Métodos: Estudo descritivo, com análise qualitativa dos dados. A coleta dos dados deu-se em um hospital pediátrico, de dezembro de 2017 a dezembro de 2018, com cuidadoras familiares de pacientes pediátricos em quimioterapia. Realizaram-se entrevistas semiestruturadas, submetidas à análise de conteúdo indutiva. Utilizaram-se conceitos da Symptom Management Theory para a discussão dos resultados. Resultados: Participaram 18 cuidadoras familiares. Foram citados pelas participantes: sintomas físicos, principalmente fraqueza, alopecia, baixa imunidade, dor, mucosite, constipação, náuseas e vômitos; sintomas emocionais ou psicossociais, como tristeza e alterações de humor; e sintomas constitucionais, como inapetência e febre. Medidas farmacológicas e não farmacológicas foram mencionadas no gerenciamento dos sintomas e dos efeitos adversos. Conclusão: As participantes demonstraram habilidades para identificar e gerenciar os sintomas da quimioterapia. Conhecer a experiência dessas famílias pode auxiliar o enfermeiro no planejamento do cuidado e de intervenções que minimizem esses eventos.

\section{DESCRITORES}

Neoplasias; Tratamento Farmacológico; Efeitos Colaterais e Reações Adversas Relacionados a Medicamentos; Cuidadores; Enfermagem Pediátrica.

\section{RESUMEN}

Objetivo: Describir los síntomas asociados al tratamiento quimioterapico y las estrategias utilizadas para su gestión en la perspectiva de cuidadores familiares de pacientes oncológicos pediátricos. Método: Estudio descriptivo, con análisis cualitativo de los datos. La colecta de los datos ocurrió en un hospital pediátrico, entre los meses de diciembre de 2017 y diciembre de 2018, con cuidadores familiares de pacientes pediátricos en tratamiento quimioterapico. Se realizaron entrevistas semiestructuradas sometidas al análisis de contenido inductivo. Se utilizaron conceptos de la Symptom Management Theory para la discusión de los resultados. Resultados: Participaron 18 cuidadoras familiares. Fueron citados por las participantes: síntomas físicos, principalmente, debilidad, alopecia, baja inmunidad, dolor, mucositis, constipación, mareo y vómitos; síntomas emocionales o psicosociales, como tristeza y alteraciones del humor y síntomas constitucionales como inapetencia y fiebre. Medidas farmacológicas y no farmacológicas fueron mencionadas en la gestión de los síntomas y de los efectos adversos. Conclusión: Las participantes demostraron habilidades para identificar y gestionar los síntomas de la quimioterapia. Conocer la experiencia de esas familias puede auxiliar el enfermero en la planificación del cuidado y de intervenciones que atenúen esos eventos.

\section{DESCRIPTORES}

Neoplasias; Quimioterapia; Efectos Colaterares y Reacciones Adversas Relacionados con Medicamentos; Cuidadores; Enfermería Pediátrica.

\section{REFERENCES}

1. Brasil. Ministério da Saúde; Instituto Nacional de Câncer José Alencar Gomes da Silva. Estimativa 2020: incidência de câncer no Brasil [Internet]. Rio de Janeiro: INCA; 2019 [cited 2020 jun. 11]. Available from: https:/www.inca.gov.br/sites/ufu.sti.inca.local/files/media/ document/estimativa-2020-incidencia-de-cancer-no-brasil.pdf

2. American Cancer Society. Cancer facts \& figures [Internet]. Atlanta: ACS; 2020 [cited 2020 June 11]. Available from: https://www.cancer. org/content/dam/cancer-org/research/cancer-facts-and-statistics/annual-cancer-facts-and-figures/2020/cancer-facts-and-figures-2020.pdf

3. Di Battista A, Dupuis LL, Cassidy M, Portwine C, Johnston DL, Pradier Silva M, et al. Parent attributions about child symptoms related to cancer therapy. J Pediatr Oncol Nurs. 2017;34(1):44-50. https://doi.org/10.1177/1043454215628002

4. Miller KD, Siegel RL, Lin CC, Mariotto AB, Kramer JL, Rowland JH, et al. Cancer treatment and survivorship statistics, 2016. CA Cancer J Clin. 2016;66(4):271-89. https://doi.org/ 10.3322/caac.21349

5. Brasil. Ministério da Saúde; Agência Nacional de Vigilância Sanitária. Farmacovigilância [Internet]. Brasília: ANVISA; 2020 [cited 2020 jun. 11]. Available from: http://portal.anvisa.gov.br/farmacovigilancia

6. World Health Organization. Glossary of terms in pharmacovigilance [Internet]. Geneva: WHO; 2018 [cited 2020 June 11]. Available from: https://www.who-umc.org/global-pharmacovigilance/global-pharmacovigilance/glossary/

7. Armstrong TS. Symptoms experience: a concept analysis. Oncol Nurs Forum. 2003;30(4):601-6. https://doi.org/10.1188/03.ONF.601-606

8. Torres V, Nunes MDR, Silva-Rodrigues FM, Bravo L, Adlard K, Secola R, et al. Frequency, severity, and distress associated with physical and psychosocial symptoms at home in children and adolescents with cancer. J Pediatr Health Care. 2019;33(4):404-14. https://doi. org/10.1016/j.pedhc.2018.11.007

9. Chitra P, Priya MB. Awareness regarding adverse effects of chemotherapy among parents of children attending oncology units of AIMS. Int J Nurs Care. 2014;2(2):20. https://doi.org/10.5958/2320-8651.2014.01264.2

10. Almico T, Faro A. Coping of caregivers of children with cancer in chemotherapy process. Psicol Saúde Doenças. 2014;15(3):723-37. https://doi.org/10.15309/14psd150313

11. Gonzalez-Mercado VJ, Williams PD, Williams AR, Pedro E, Colon G. The symptom experiences of Puerto Rican children undergoing cancer treatments and alleviation practices as reported by their mothers. Int J Nurs Pract. 2017;23(1). https://doi.org/10.1111/ijn.12500

12. Linder LA, Al-Qaaydeh S, Donaldson G. Symptom characteristics among hospitalized children and adolescents with cancer. Cancer Nurs. 2018;41(1):23-32. https://doi.org/ 10.1097/NCC.0000000000000469

13. Silva MC, Lopes Júnior LC, Nascimento LC, Lima RA. Fatigue in children and adolescents with cancer from the perspective of health professionals. Rev Latino Am Enfermagem. 2016;24:e2784. https://doi.org/10.1590/1518-8345.1159.2784

14. Sarmento LS, Silva LF, Goes FG, Paiva ED, Depianti JR. A visão dos familiares quanto às orientações realizadas junto à criança em quimioterapia antineoplásica. Cogitare Enferm. 2016;21(1):1-9. http://dx.doi.org/10.5380/ce.v21i1.42835 
15. Smith MJ, Liehr PR. Middle range theory for nursing. New York: Springer; 2018.

16. Newcomb P. Using symptom management theory to explain how nurse practitioners care for children with asthma. J Theory Constr Test. 2010;14(2):40-4.

17. Loades ME, Kagee A. Exploring our understanding of fatigue among adolescents living with HIV: highlighting the unknown. J Health Psychol. 2019;24(1):125-36. https://doi.org/ 10.1177/1359105317710320

18. Dodd M, Janson S, Facione N, Faucett J, Froelicher ES, Humphreys J, et al. Advancing the science of symptom management. J Adv Nurs. 2001;33(5):668-76. https://doi.org/ 10.1046/j.1365-2648.2001.01697.x

19. Fontanella BJB, Luchesi BM, Saidel MGB, Ricas J, Turato ER, Melo DG. Amostragem em pesquisas qualitativas: proposta de procedimentos para constatar saturação teórica. Cad Saúde Pública. 2011;27(2):388-94. https://doi.org/10.1590/S0102-311X2011000200020

20. O'Reilly M, Parker N. Unsatisfactory saturation: a critical exploration of the notion of saturated sample sizes in qualitative research. Qual Res. 2012;13(2):190-7. https://doi.org/10.1177/1468794112446106

21. Elo S, Kyngäs H. The qualitative content analysis process. J Adv Nurs. 2008;62(1):107-15. https://doi.org/10.1111/j.1365-2648.2007.04569.x

22. Tong A, Sainsbury P, Craig J. Consolidated criteria for reporting qualitative research (COREQ): a 32 -item checklist for interviews and focus groups. Int J Qual Health Care. 2007;19(6):349-57. https://doi.org/10.1093/intqhc/mzm042

23. Kudubes AA, Bektas M, Ugur O. Symptom frequency of children with cancer and parent quality of life in Turkey. Asian Pac J Cancer Prev. 2014;15(8):3487-93. https://doi.org/ 10.7314/apjcp.2014.15.8.3487

24. Nunes MDR, Nascimento LC, Fernandes AM, Batalha L, De Campos C, Gonçalves A, et al. Pain, sleep patterns and health-related quality of life in paediatric patients with cancer. Eur J Cancer Care (Engl). 2019;28(4):e13029. https://doi.org/10.1111/ecc.13029

25. Rodgers C, Hooke MC, Ward J, Linder LA. Symptom clusters in children and adolescents with cancer. Semin Oncol Nurs. 2016 Nov;32(4):394-404. https://doi.org/ 10.1016/j.soncn.2016.08.005

26. Nap-van der Vlist MM, Dalmeijer GW, Grootenhuis MA, van der Ent CK, van den Heuvel-Eibrink MM, Wulffraat NM, et al. Fatigue in childhood chronic disease. Arch Dis Child. 2019;104(11):1090-5. http://dx.doi.org/10.1136/archdischild-2019-316782

27. Aburn G, Gott M. Education given to parents of children newly diagnosed with acute lymphoblastic leukemia: the parent's perspective. Pediatr Nurs. 2014;40(5):243-8,256

28. Williams PD, Piamjariyakul U, Shanberg R, Williams AR. Monitoring and alleviation of symptom occurrence and severity among thai children and adolescents during cancer treatments. J Pediatr Oncol Nurs. 2015;32(6):417-28. http://dx.doi.org/ 10.1177/1043454214563754

29. Crisp CL. Faith, hope, and spirituality: supporting parents when their child has a life-limiting illness. J Christ Nurs. 2016;33(1):14-21.

30. Nicholas DB, Barrera M, Granek L, D'Agostino NM, Shaheed J, Beaune L, et al. Parental spirituality in life-threatening pediatric cancer. J Psychosoc Oncol. 2017;35(3):323-34. http://dx.doi.org/10.1080/07347332.2017.1292573

31. Leite ACAB, Garcia-Vivar C, Neris RR, Alvarenga WA, Nascimento LC. The experience of hope in families of children and adolescents living with chronic illness: a thematic synthesis of qualitative studies. J Adv Nurs. 2019;75(12):3246-62. http://dx.doi.org/10.1111/jan.14129

\section{Financial Support}

National Council for Scientific and Technological Development (CNPq). Process: 312339/2017-8. Undergraduate Scientific Research Scholarship (PIBIC). 